\title{
Effect of partial root-zone irrigation system on seed quality changes of Persian clover (Trifolium resupinatum L.) during seed development and maturation
}

\author{
Eskandari HAMDOLLAH ${ }^{1}$, Alizadeh-Amraie ASHRAF ${ }^{2}$
}

Received March 28, 2017; accepted August 02, 2017.

Delo je prispelo 28. marca 2017, sprejeto 02. avgusta 2017.

\begin{abstract}
A field experiment was conducted in Aleshtar, Iran during 2015-16 growing season to evaluate the effect of limited water supply during seed filling period on seed quality changes of Persian clover. The experiment was carried out as a $2 \times 6$ factorial with three replications. Irrigation systems including conventional (all root system was irrigated) and partial rootzone irrigation (half of root system exposed to dry soil and the other half was watered) and harvest time (initiated from 10 days after flowering (DAA) and continued on six occasions at 5-day intervals) were used as treatments. Germination percentage, seedling dry mass, electrical conductivity and 1000 -seed mass were used as seed quality traits. Seed quality attributes were significantly affected by harvest time and irrigation system, but the interaction of irrigation system $\times$ harvest time was not significant. While seed mass and electrical conductivity were not significantly affected by irrigation system, seedling dry mass and germination percentage were reduced under deficit irrigation. Partial rootzone irrigation reduced seed quality, Persian clover needs to experience no water deficit during seed formation and maturation period to produce high quality and quantity seeds.
\end{abstract}

Key words: persian clover; deficit irrigation; germination performance; seed production
IZVLEČEK

\author{
VPLIV DELNEGA NAMAKANJA KORENIN NA \\ SPREMEMBE V KAKOVOSTI SEMENA PERZIJSKE \\ DETELJE (Trifolium resupinatum L.) MED NJEGOVIM \\ RAZVOJEM IN ZORENJEM
}

$\mathrm{Za}$ ovrednotenje vpliva omejene preskrbe $\mathrm{z}$ vodo $\mathrm{v}$ fazi polnjenja semen perzijske detelje na spremembe njihove kakovosti je bil v Aleshtarju, Iran, v rastni sezoni 2015-16 izveden poljski poskus. Poskus je bil $2 \times 6$ faktorski poskus $\mathrm{s}$ tremi ponovitvami. Obravnavanja so obsegala običajno namakanje (namakan je bil celoten korerninski sistem), delno namakanje (polovica koreninskega sistema je bila namakana, druga je ostala suha) in čas pobiranja semen (začetek 10 dni po cvetenju (DAF) in nato šestkrat v 5-dnevnih intervalih). Odstotek kalitve, suha masa kalic, električna prevodnost vode, $\mathrm{v}$ kateri je bilo namočeno vzorčeno seme in masa 1000 semen so bili uporabljeni kot znaki kakovosti semena. Na znake kakovosti semena sta značilno vplivala čas pobiranja semena in način namakanja posevka medtem, ko njuna interakcija ni imela značilnega vpliva. $\mathrm{Na}$ maso semen in električno prevodnost načina namakanja nista značilno vplivala, suha masa kalic in odstotek kalitve sta se ob pomanjkanju namakanja zmanjšala. Delno namakanje korenin je zmanjšalo kakovost semena, kar kaže, da potrebuje perzijska detelja za uspešno tvorbo in zorenje kakovostnega semena razmere brez pomanjkanja vode.

Ključne besede: perzijska detelja; deficitarno namakanje; kalitev; tvorba semena

\section{INTRODUCTION}

Persian clover (Trifolium resupinatum L.), originated from central Asia, is an important legume fodder crop in West-Asia, especially Iran. However, there is a serious shortage of high quality seed in the region, resulting from less attention of farmers to seed production of Persian clover. Furthermore, clover seed production also depends on the environmental conditions such as water limitation, prevailing during seed formation and maturation (Bakhiet et al., 2012).

Adequate water supply is necessary for optimum growth and seed production of crops. However, available water

\footnotetext{
$1 \quad *$ Associate Professor, Department of Agriculture, Payame Noor University, Tehran, Iran, corresponding author: ehamdollah@ gmail.com

2 Instructor, Department of Agriculture, Payame Noor University, Tehran, Iran
} 
resources for agriculture have been decreasing in recent years, emphasizing on necessity of the efficient use of the limited water resources (Kang and Zhang, 2004). Water deficit conditions not only reduce seed yield of crops (Ghassemi-Golezani et al., 1997) but also negatively affect seed quality. In this case, ZehtabSalmasi et al (2006) showed that limited water supply during seed development and maturation led to significant reduction in seed quality of dill. However, some researches revealed that seed quality was not significantly affected by water limitation during seed filling period (Eskandari et al., 2015; Vieira et al., 1992). These results show that different crops have different reaction to water shortage during seed filling period. Thus, the response of seed quality to low water supply during seed formation and maturation should be evaluated separately in each crop. Partial root-zone irrigation (PRI) is a new water-saving technique for substantial saving of irrigated water. Although the beneficial effects of this limited irrigation system has already investigated on several crops (Davies et al., 2002; Dasgan et al., 2009), its effects on seed quality need to be more documented.

Although it has been reported that irrigation scheduling affects the seed production process of clover (Singh and Kang, 2004), the knowledge about the influence of water deficit on seed quality of Persian clover is inconsistent and limited. Therefore, the current research was conducted to evaluate the reaction of seed quality of Persian clover to water shortage (induced by partial root-zone irrigation system) during seed development and maturation and respond the following questions: 1 . What is the best developmental stage of Persian clover under well and limited irrigation at which maximum seed quality is attained? 2. In some crops such as lentil (Dabbagh-Mohammadi Nasab et al., 2001) maximum seed quality was achieved earlier under limited water supply. Does such trend also occur in Persian clover?

\section{MATERIALS AND METHODS}

The experiment was conducted in a research field in Aleshtar, Iran $\left(33^{\circ} 51^{\prime} \mathrm{N}, 48^{\circ} 15^{\prime} \mathrm{E}\right)$ during 2015-2016 growing season. The effects of two factors including irrigation regime and harvest time were evaluated on the quality of Persian clover seed during seed formation and maturation. A $2 \times 5$ factorial based on randomized complete block design (RCBD) with three replications was employed to compare the treatments. The two irrigation regimes were conventional irrigation in which all root system parts were irrigated and fixed partial root-zone irrigation (PRI) in which half of root system was irrigated and half of it was exposed to dry soil. For partial root-zone irrigation system, cultivation furrows were watered every other furrows.

Persian clover seeds cultivar Aleshter, which is commonly cultivated in the region, were sown on 13 November 2015. All plots were fertilized with the same amount of fertilizer, containing $75 \mathrm{~kg} \mathrm{ha}^{-1} \mathrm{P}_{2} \mathrm{O}_{5}, 75 \mathrm{~kg}$ $\mathrm{ha}^{-1}$ and $20 \mathrm{~kg} \mathrm{ha}^{-1} \mathrm{~N}$ (as a starter fertilizer). At the end of March 2016, when seasonal precipitation ended and irrigation was essential, treatments of the experiment were started coinciding with the end of flowering and onset of seed filling period. Since Persian clover was cultivated for seed production, no forage cutting was applied during growing season. After flowering (a plot was considered as having flowered, when a minimum of $60 \%$ of its plants flowered) plants from an area of 0.5 $\mathrm{m}^{2}$ from each plot were harvested on six occasions, at 5day intervals and 1000-seed mass, germination percentage, electrical conductivity of seed lot and seedling dry mass were determined.
The 1000-seed mass was determined by using the mean mass of 200 seeds in three replicates, using proportion. Two moist filter papers were placed in sterilized Petri dishes. Petri dishes had a diameter and a depth of $10 \mathrm{~cm}$ and $2 \mathrm{~cm}$, respectively. Then, four replicates of 50 dried seeds (seeds were oven-dried at $75{ }^{\circ} \mathrm{C}$ for 48 hours) from each sample were placed in sterilized Petri dishes and incubated at $18{ }^{\circ} \mathrm{C}$ for 10 days and germination percentage was determined. Both seminal roots and shoots of germinated seeds were cut and dried in an oven at $75 \pm 2{ }^{\circ} \mathrm{C}$ for 24 hours. The dried seminal roots and shoots were weighed as seedling dry mass. Electrical conductivity of seed leachates was determined using two replicates of 50 fresh seeds from each sample. Seeds were weighed $\left(\mathrm{SM}_{1}\right.$ and $\left.\mathrm{SM}_{2}\right)$ and each replicate immersed in $250 \mathrm{ml}$ deionized water in a container at $20{ }^{\circ} \mathrm{C}$ for 24 hours. The seed-soak water was then gently decanted and electrical conductivity (EC) was measured $\left(\mathrm{EC}_{1}\right.$ and $\left.\mathrm{EC}_{2}\right)$ using $\mathrm{EC}$ meter instrument. The following equation was applied to calculate conductivity (Powell et al., 1984):

$$
\mathrm{EC}\left(\mu \mathrm{s} \mathrm{cm}^{-1} \mathrm{~g}^{-1}\right)=\left[\left(\mathrm{EC}_{1} / \mathrm{SM}_{1}\right)+\left(\mathrm{EC}_{2} / \mathrm{SM}_{2}\right)\right] / 2
$$

The data were tested for normal distribution. The data of germination percentage were transformed through inverse square root. However, for better comparison, the data were introduced as percentage in figures. ANOVA and the comparison of the means were carried out; using MSTATC statistical software (Khanlou, 2004) and Duncan's multiple range test, respectively. 


\section{RESULTS AND DISCUSSION}

Effects of harvest time and irrigation system were significant $(P \leq 0.05)$ on seedling dry mass and germination percentage of clover seeds. Electrical conductivity and 1000-seed mass were significantly influenced $(P \leq 0.05)$ by harvest time, but irrigation system had no significant effect on these traits. The interaction of irrigation system $\times$ harvest time was not significant on all traits (Table 1).

Table 1: The analysis of variance for the effect of irrigation method and harvesting time on qualitative indices of Persian clover

\begin{tabular}{llllll}
\hline $\begin{array}{l}\text { Source of } \\
\text { Variance }\end{array}$ & df & \multicolumn{2}{l}{ Mean Square } & & \\
\cline { 3 - 5 } & & seedling dry mass & germination & $\begin{array}{l}1000 \text {-grain } \\
\text { mass }\end{array}$ & $\begin{array}{l}\text { Electrical } \\
\text { Conductivity }\end{array}$ \\
\hline Replication & 2 & $4.19^{\mathrm{ns}}$ & $4.08^{\mathrm{ns}}$ & $0.003^{\mathrm{ns}}$ & $267.22^{\mathrm{ns}}$ \\
$\begin{array}{l}\text { Irrigation (I) } \\
\text { Harvest time (H) }\end{array}$ & 1 & $148.03^{*}$ & $182.25^{* *}$ & $0.039^{*}$ & $252.18^{\mathrm{ns}}$ \\
$\mathrm{I} \times \mathrm{H}$ & $175.56^{* *}$ & $4108.05^{* *}$ & $0.479^{* *}$ & $583.08^{*}$ \\
error & 5 & $7.96^{\mathrm{ns}}$ & $8.89^{\mathrm{ns}}$ & $0.003^{\mathrm{ns}}$ & $76.43^{\mathrm{ns}}$ \\
\hline $\mathrm{CV}(\%)$ & 22 & 19.34 & 6.75 & 0.015 & 0.836 \\
\hline
\end{tabular}

$\mathrm{ns},{ }^{*}$ and ${ }^{* *}$ indicate not significant, significant at $\mathrm{P} \leq 0.05$ and $\mathrm{P} \leq 0.01$, respectively

Low water supply, induced by partial root-zone irrigation system, reduced seedling dry mass and germination percentage (Table 1). Although low watering did not significantly changed seed mass of Persian clover, this does not mean that no seed yield reduction was occurred. Seed yield is depended on seed size (mass) and number. However, seed yield of Persian clover was significantly $(P \leq 0.01)$ reduced by limited irrigation (the seed yield of Persian clover under conventional and partial root-zone irrigation systems was $472 \mathrm{~kg} \mathrm{ha}^{-1}$ and $287 \mathrm{~kg} \mathrm{ha}^{-1}$, respectively) showing that seed number per plant experienced reduction under water deficit condition. Low seedling dry mass, resulted from low germination percentage, and lower seed yield revealed that Persian clover need to be well watered during seed formation and maturation to produce appropriate seed in terms of quality and quantity.
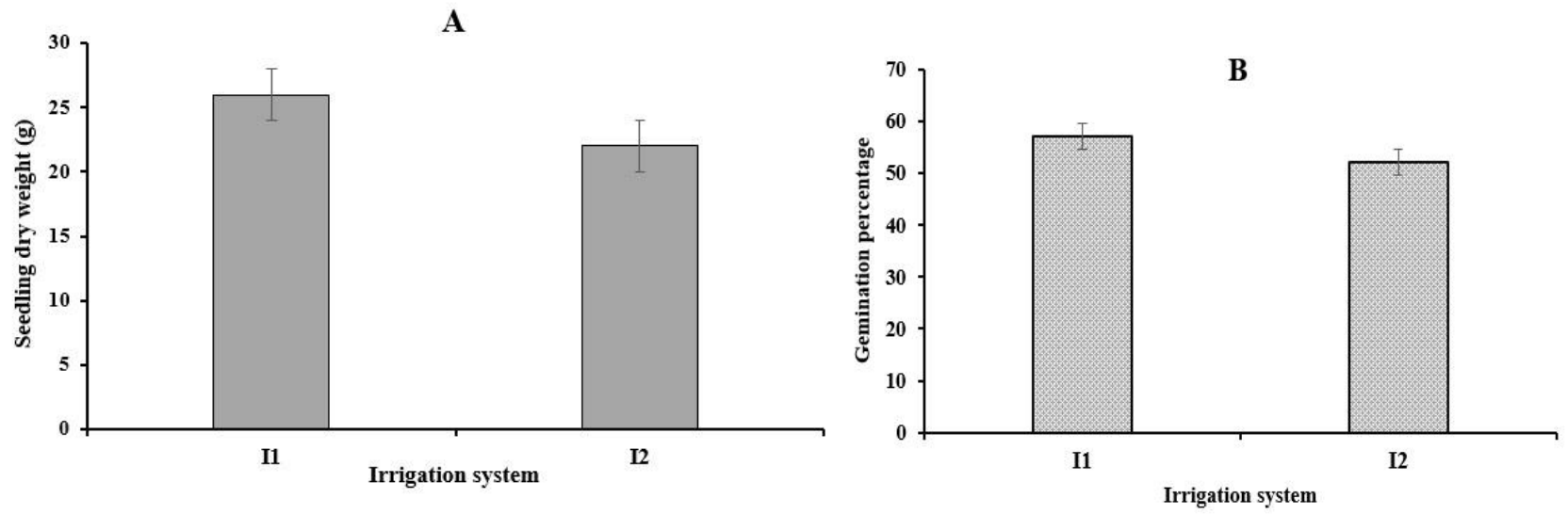

Figure 1: Effect of irrigation system on seedling dry mass (A) and germination percentage (B) of Persian clover. $\mathrm{I}_{1}$ : conventional irrigation; $\mathrm{I}_{2}$ : Partial root-zone irrigation

With increasing maturity, seed mass of Persian clover were increased. The highest seed mass was attained at 35 days after flowering (DAF). However, seed mass at this date was not significantly $(\mathrm{P} \leq 0.01)$ different with the dates of 25 DAF and 30 DAF. Therefore, it can be declared that Persian clover reached the highest seed mass at 25 DAF (Figure 2) .Completing the necessary structures of seed during maturation and increasing the 
number of endospermic cells have been reported to be two main reasons for increasing seed dry mass during seed filling period (Madandoust, 2006). However, it has been observed that at the end of seed filling period, increasing in seed cells respiration may lead to reduction of seed dry mass (Eskandari et al, 2013). However, such a seed dry mass reduction was not recorded in this research.

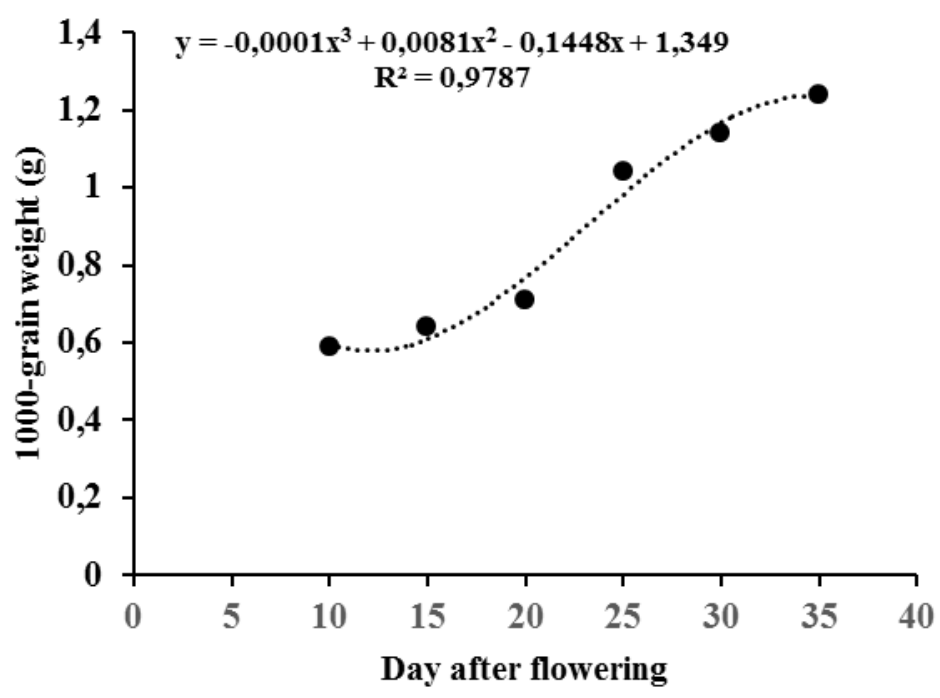

Figure 2: 1000-seed mass of Persian clover during seed development and maturation

Seedling dry mass has an increasing trend (Figure 2) reaching to its highest value at $30 \mathrm{DAF}$. The highest seedling dry mass was achieved (30 DAF) five days after reaching the highest seed mass (25 DAF). Thus, achieving the maximum mass of seed and seedling dry mass were not coincided (Figure 2 and Figure 3).

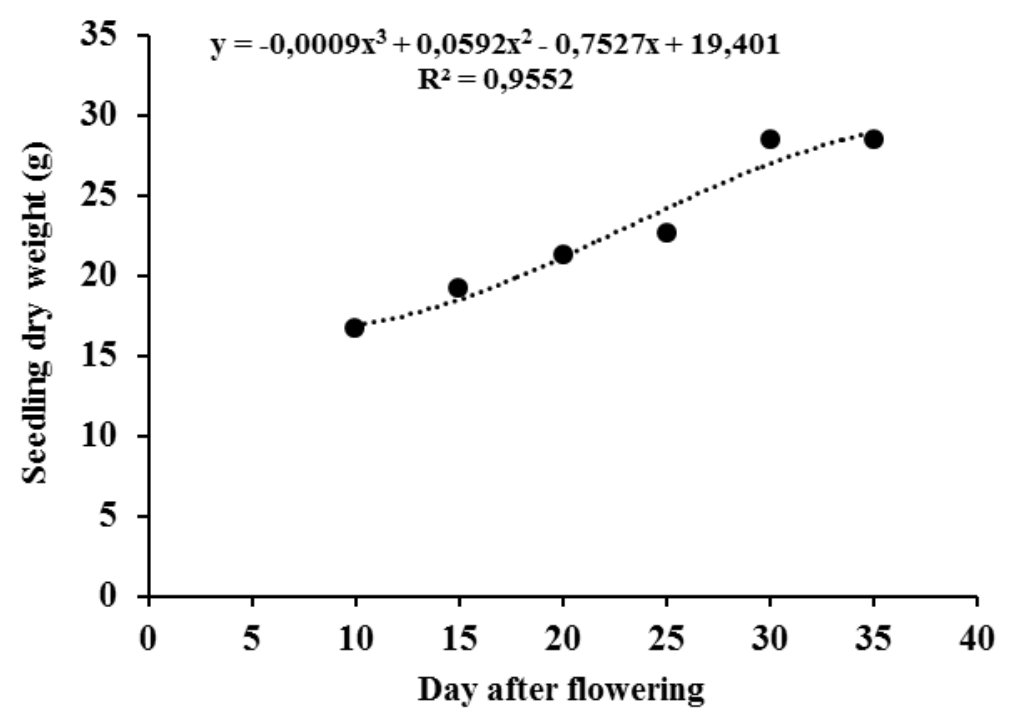

Figure 3: The variation of seedling dry mass of Persian clover during seed development and maturation 
Germination percentage of Persian clover was increased with increasing in harvest time. The highest germination percentage was recorded at the last harvest stage (35 DAF). In the other word, the time of reaching maximum germination was not coincided with the highest seed mass. It has been declared that low germination, seed mass and seedling dry mass at early stages of seed growth and development is related to seed immaturity (Ghassemi-Golezani et al., 1996). In the early stages of seed growth and development, seeds essential structures are not fully formed (Rasyad et al., 1990) resulting in low seed germination performance.

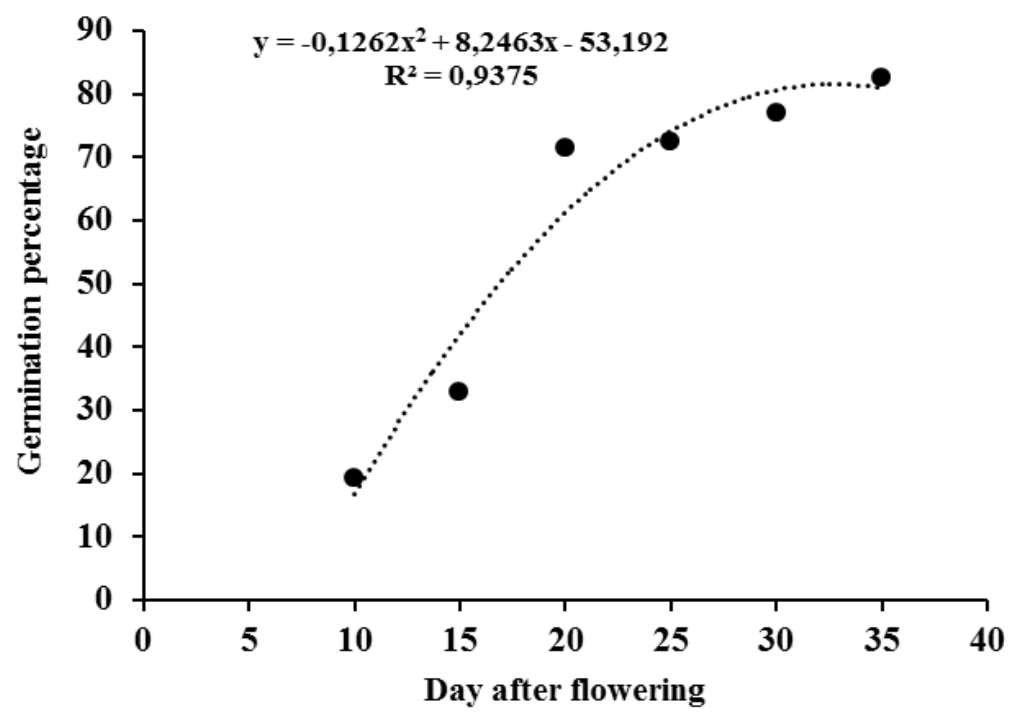

Figure 4: The variation of germination percentage of Persian clover during seed development and maturation

Electrical conductivity of Persian clover seed was lowered as harvest time increased. The lowest electrical conductivity was observed at 35 DAF which was not significantly $(\mathrm{P} \leq 0.01)$ difference with harvest time of 25 DAF (Figure 4). In fact, the time of reaching minimum electrical conductivity was not coincided with the highest value of seed mass. Higher electrical conductivity shows immaturity of seed. In early stages of seed growth and development, internal materials of seed leak out, resulting in higher electrical conductivity. However, with the increasing in seed growth and development and formation and consolidation of necessary structures, seed cell leaking decreases (Ghassemi-Golezani et al., 1997) resulting in the reduction of electrical conductivity.

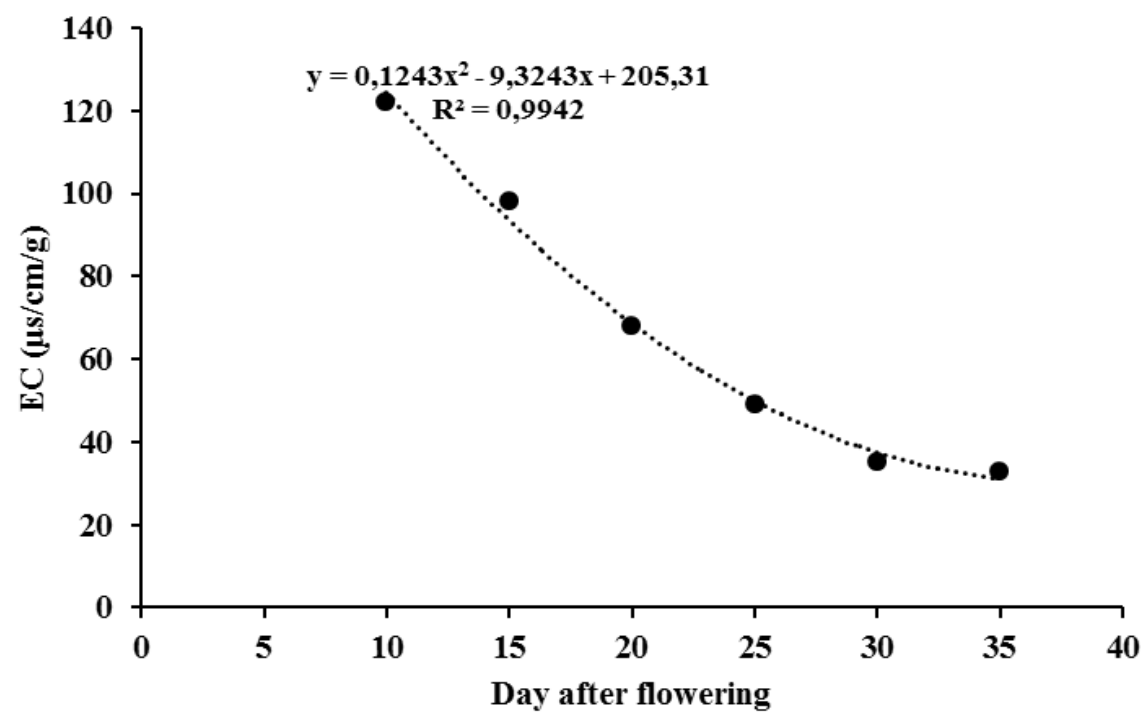

Figure 5: The variation of electrical conductivity of Persian clover during seed development and maturation 
According to Harrington (1972), maximum quality of seeds is attained at the end of the seed filling period, thereafter seeds quality declines because they then begin to age. This stage was termed physiological maturity (Sanhewe and Ellis, 1996). Although Harrington's (1972) hypothesis has been shown to be occurred in some crops such as triticale (Bishnoi, 1974), wheat (Rasyad et al. 1990) and maize (Tekrony and Hunter, 1995), it has been also observed that maximum seed quality was only attained sometime after the end of the seed filling period, contradicting Harrington's hypothesis (Demir and Smith, 2001, Demir et al. 2002).
In the current experiment, while the highest seed mass attained at 25 days after anthesis (DAA), seed germination, seedling dry mass and electrical conductivity were improved up to 30 DAA. Thus, the results of this experiment revealed that physiological maturity of Persian clover is occurred sometimes after mass maturity. In other words, this experiment does not support Harington's (1972) hypothesis. In conclusion, Persian clover reached to highest seed quality 30 DAA and needs to experience no water deficit during seed formation and maturation period to produce high quality and quantity seeds.

\section{REFERENCES}

Bakheit, B. R., Ali, M.A. and Helmy, AA. (2012). The influence of temperature, genotype and genotype $\times$ temperature interaction on seed yield of berseem clover. Asian Journal of Crop Science, 4, 63-71. doi:10.3923/ajcs.2012.63.71

Beshoni, W.R. (1974). Physiological maturity of seeds in Triticale hexaploid. Crop Science, 14, 819-821. doi:10.2135/cropsci1974.0011183X001400060012 $\mathrm{x}$

Dabbagh-Mohammadi Nasab, A., Ghassemi-Golezani, K., Rahim-Zadeh Khoie, F. and Moghaddam, M. (2001). Effect of water limitation on seed quality of two lentil genotypes during seed development and maturation. Iranian Journal of Agricultural Science, 2, 91-102.

Dasgan, H.Y., Kusvuran, S. and Kirda, C. (2009). Effect of short duration partial root-zone drying on soilless grown tomato crop. Journal of Food Agriculture and Environment, 7, 83-91.

Davies, W. J., Wilkinson, S. and Loveys, B. (2002). Stomatal control by chemical signaling and the exploitation of this mechanism to increase water use efficiency in agriculture. New Phytology, 135, 449-460. doi:10.1046/j.0028-646X.2001.00345.x

Demir, I. and Samit, Y. (2001). Seed quality in relation to fruit maturation and seed dry weight during development in tomato. Seed Science and Technology, 29, 453-462.

Demir, I., Mavi, K., Sermenli, T. and Ozcoban, M. (2002). Seed development and maturation in Aubergine (Solanum melongena L.). Gartenbanwissenschaft, 67,148-154.

Eskandari, H., Kazemi, K. and Ebadipour, A. (2013). Seed technology. Behtapajoohesh Press, Isfahan.

Eskandari, H., Hamid, A. and Alizadeh-Amraie, A. (2015). Development and maturation of sesame
(Sesamum indicum) seeds under different water regimes. Seed Science and Technology, 43, 1-4. doi:10.15258/sst.2015.43.2.03

Ghassemi-Golezani, K., Soltani, A. and Atashi, A. (1997). The effect of water limitation in the field on seed quality of maize and sorghum. Seed Science and Technology, 25, 321-323.

Harington, J.F. (1972). Seed storage and longevity. In Seed Biology (ed. T. T. Kozlowski), volume 3, pp. 145-245, Academic Press, New York. doi:10.1016/B978-0-12-395605-7.50009-0

Khanlou, K. (2004). MSTATC illustrated manual. Dibagaran Institute Press, Tehran.

Madandoust, M. (2006). Assessment of kernel weight increase limitation in corn hybrids. Journal of Agricultural Science, 2, 379-386.

Powell, A., Don, A., Haigh, R., Phillips, G., Tonkin, J. and Wheaton, O.E. (1984). Assessment of repeatability of controlled deterioration vigour test both within and between laboratories. Seed Science and Technology, 12, 421-427.

Rasyad, D.A, Van Sanfors, D.A. and Tekrony, D.M. (1990). Changes in seed viability and vigour during wheat seed maturation. Seed Science and Technology, 18, 259-267.

Sanhewe, A.J. and Ellis, R.H. (1996). Seed development and maturation in Phaseolus vulgaris II. Post anthesis longevity in air-dry storage. Journal of Experimental Botany, 47, 959-965. doi:10.1093/jxb/47.7.959

Singh, A. and Kang, J.S. (2004). Effect of agrotechniques on seed production potential of new berseem cultivar. Range management and Agroforestry, 25, 80-81. 
Effect of partial root-zone irrigation system ... (Trifolium resupinatum L.) during seed development and maturation

Tekrony, D.M. and Hunter, J.L. (1995). Effect of seed maturation and genotype on seed vigour in maize. Crop Science, 35, 857-862. doi:10.2135/cropsci1995.0011183X003500030037 $\mathrm{x}$

Vieira, R.D., Tekrony, D.M. and Egli, D.B. (1992). Effect of drought and defoliation stress in the field on soybean seed germination and vigour. Crop
Science,

32 ,

471-475. doi:10.2135/cropsci1992.0011183X003200020037 $\mathrm{X}$

Zehtab-Salmasi, S., Ghassemi-Golezani, K. abd Moghbeli, S. (2006). Effect of sowing date and limited irrigation on the seed yield and quality of Dill (Anethum graveolens L.). Turkish Journal of Agriculture and Forestry, 30, 281-286. 